\title{
ENSAIO DE TRAÇÃO EM COMPÓSITOS DE MATRIZ POLIÉSTER REFORCADOS POR FIBRAS DE EUCALIPTO*
}

\author{
Anna Carolina Cerqueira Neves ${ }^{1}$ \\ Caroline Gomes de Oliveira ${ }^{1}$ \\ Marcos Vinícius Fonseca Ferreira ${ }^{1}$ \\ Frederico Muylaert Margem ${ }^{2}$ \\ Sérgio Neves Monteiro ${ }^{3}$
}

\begin{abstract}
Resumo
Atualmente, materiais alternativos têm sido pesquisados, sendo os compósitos de matriz poliméricas reforçados com fibras naturais um desses tipos de materiais. $O$ fato que torna as fibras naturais uma ótima opção são suas vantagens ambientais e seu relativo baixo custo. No caso do eu eucalipto, este também possui um alto cultivo no Brasil. Além disso, as fibras naturais apresentam características de interface com a matriz polimérica que favorecem as propriedades mecânicas pela estrutura do compósito. Esse presente trabalho analisa as propriedades de tração do compósito de matriz poliéster reforçado com a incorporação de fibras de eucalipto em 10,20 e $30 \%$ em fração volumétrica, que foram preparados alinhando as fibras nas matrizes e curadas por 24 horas em temperatura ambiente, por volta de $25^{\circ} \mathrm{C}$. Os corpos de prova foram testados numa máquina Instron e os resultados mostraram um aumento na resistência à tração conforme o aumento do volume de fibras incorporadas.
\end{abstract}

Palavras-chave: Ensaio de tração; Matriz poliéster; Fibras de eucalipto; Compósitos.

\section{TENSILE PROPERTIES OF POLYESTER MATRIX COMPOSITES REINFORCED WITH EUCALYPTUS FIBERS}

\section{Abstract}

Nowadays, alternative materials have been really investigated and polymeric matrices composites reinforced with natural fibers are one of those types of materials. The facts that make natural fibers a great option are their environmental advantages and relatively low cost. In the case of eucalyptus, it has also a large cultivation in Brazil. Besides that, the natural fiber presents interfacial characteristics with polymeric matrices that favor the mechanical properties by the composite structure. This present work analyses the tensile properties of a polyester matrix composite reinforced with 10, 20 and $30 \%$ in volume fraction of eucalyptus fibers incorporation, which were prepared by laying down the fibers unto the plates along the entire length and cured in 24 hours in room temperature, around $25^{\circ} \mathrm{C}$. They were tested in an Instron Machine and the results showed the increase of the tensile strength with the increase of fiber amount incorporation.

Keywords: Tensile properties; Polyester matrix; Eucalyptus fibers; Composites.

1 Graduando(a) em Engenharia Metalúrgica e de Materiais, bolsista de iniciação científica, LAMAV, UENF, Campos dos Goytacazes, Rio de Janeiro - Brasil.

2 Pós doutorando em Ciência e Engenharia de Materiais, Pós-Doutorando, LAMAV, UENF, Campos dos Goytacazes, Rio de Janeiro - Brasil.

3 Professor PhD, IME, Rio de Janeiro, Rio de Janeiro - Brasil. 


\section{INTRODUCTION}

In recent years, there has been an increase application of natural fibers as reinforcement of polymeric matrix composites in several industrial sectors, with special participation in automobile components ${ }^{(1-3)}$. The advantage of natural fibers, especially those extracted from plants, over the glass fiber are presently a great motivation for the increasing use of "green" composites in automobiles (4-6). Glass fiber is more expensive, heavier and abrasive to processing equipment.

Moreover, this synthetic fiber presents a health risk when inhaled and its production is associated with $\mathrm{CO}_{2}$ emissions. None of these shortcomings apply to lignocellulosic fibers that, in addition, are renewable, biodegradable and neutral with respect to greenhouse gases, the major responsible for global warming. Application of natural fiber composites is rapidly increasing in the automobile industry with annual growth rates above $20 \%$ (7).

Less known natural fibers like piassava ${ }^{(8)}$, ramie ${ }^{(9)}$, curaua ${ }^{(10)}$ and buriti ${ }^{(11)}$ sisal (12) and other are currently being investigated for their potential as composite reinforcement. Eucalyptus is one the lignocellulosic fiber with least knowledge as far as mechanical properties are concerned. Characterizations of these composites are being carried out for different polymer matrices and mechanical tests (12-22).

However, no tensile characterization was done so far for polymer composites reinforced with eucalyptus fibers. Therefore, the objective of this work was to conduct the tensile tests of polyester matrix composites reinforced with eucalyptus fibers.

\section{EXPERIMENTAL PROCEDURE}

The material used in this work was untreated eucalyptus fiber extracted from the stem eucalyptus plant supplied by Desigan Natural Fibers Company and polyester resin. Statistical analysis were performed on one hundred fibers randomly removed from the as-received the lot. Figure 1 shows the histogram for the distribution of eucalyptus fiber diameters by considering 6 diameter intervals. From this distribution, presented elsewhere an average diameter of $0.065 \mathrm{~mm}$ was found for the as-received lot.

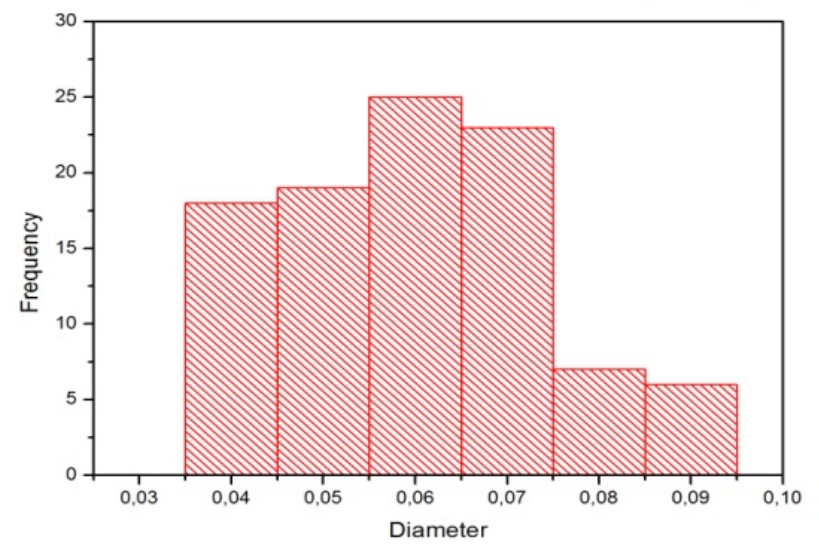

Figure 1.Distribution histogram for six diameter intervals.

For composite fabrication, the as-received eucalyptus fibers were initially cleaned and then dried at $60^{\circ} \mathrm{C}$ for 24 hours. Tensile specimens were individually prepared by laying down continuous and aligned fibers in a rectangular "dog-bone" shaped silicone mold with $5.8 \times 4.5 \mathrm{~mm}$ of reduced gage dimensions. Fibers in amounts of up 
to $30 \%$ in volume were aligned along the $35 \mathrm{~mm}$ length of the specimens, corresponding to its tensile axis. The still fluid polyester resin, plus $0.5 \%$ of caralyst based on methyl ethyl ketone, was poured onto the fibers in the mold and allowed to cure for 24 hours and at room temperature. Some composite specimens were fabricated for each fiber composition. Each specimen was room temperature tested in a model 5582 Instron universal machine at a strain rate of $3 \times 10^{-3} \mathrm{~s}^{-1}$. The fracture surface of selected specimens was gold sputtered and then analyzed by scanning electron microscopy (SEM) in a model SSX-550 Shimadzu microscope operating at an accelerating voltage of $7-15 \mathrm{kV}$.

\section{RESULTS AND DISCUSSION}

Figure 2 exemplifies the typical load vs. extension curves for different composites. These curves were recorded directly from the Instron machine and revealed that the eucalyptus fiber reinforced composites apparently present limited plastic deformation. Consequently, these composites, in principle, may be considered as brittle materials.

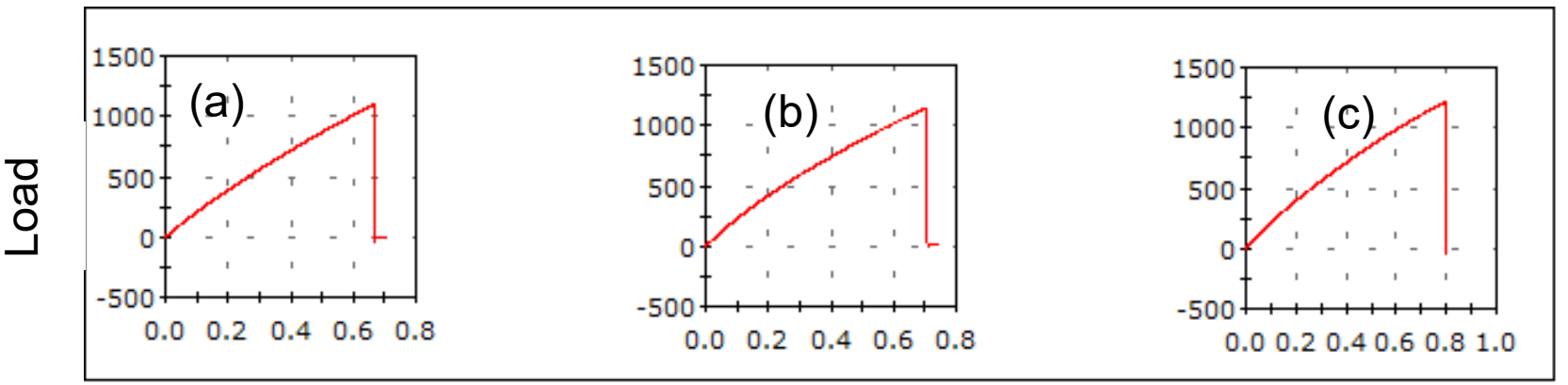

\section{Elongation}

Figure 2. Load vs. elongation curves tor polyester composites reinforced with (a) $0 \%$, (b) $10 \%$ and (c) $30 \%$ of volume fraction of eucalyptus fibers.

From the results of the load vs. elongation curves, Fig. 2, the ultimate stress (tensile strength), elastic modulus, and total strain were calculated. Table 1 shows the average values for these tensile properties for the different amounts of eucalyptus fiber investigated.

Table 1. Tensile properties for the eucalyptus fiber reinforced polyester composites.

\begin{tabular}{ccc}
\hline $\begin{array}{c}\text { Amount of } \\
\text { Eucalyptus Fiber (Vol. } \\
\text { \%) }\end{array}$ & $\begin{array}{c}\text { Tensile Strength } \\
\text { (Mpa) }\end{array}$ & $\begin{array}{c}\text { Elastic Modulus } \\
\text { (Gpa) }\end{array}$ \\
\hline $\mathbf{0}$ & $28.99 \pm 6.58$ & $0.83 \pm 0.23$ \\
$\mathbf{1 0}$ & $37.43 \pm 3.29$ & $1.88 \pm 0.16$ \\
$\mathbf{2 0}$ & $45.56 \pm 6.73$ & $1.70 \pm 0.05$ \\
$\mathbf{3 0}$ & $53.08 \pm 3.28$ & $1.75 \pm 0.13$ \\
\hline
\end{tabular}

Figure 3 plots the results of tensile strength and elastic modulus in Table 1 as a function of the volume fraction of eucalyptus fibers. In this figure it should be noted 
that both the composite tensile strength and stiffness significantly increase with the eucalyptus fiber incorporated into the polyester matrix.

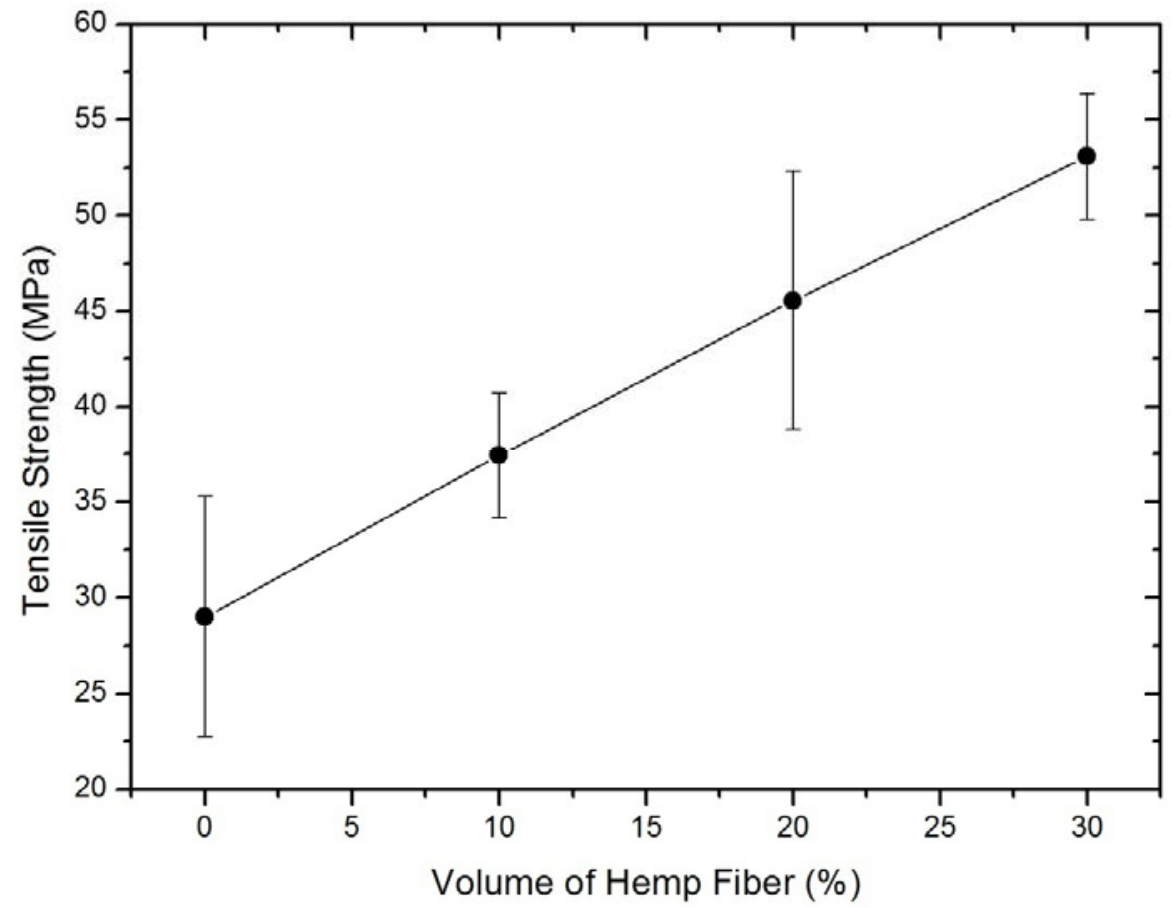

Figure 3 - Tensile strength variation with the amount of eucalyptus fiber in the composite.

The elastic modulus variation in Fig 4 could also be adjusted to a linear relation and demonstrates a relevance increase in it values with the increase of fibers in the matrix. This can be attributed to the same mechanical proprieties analyzed for the tensile strength.

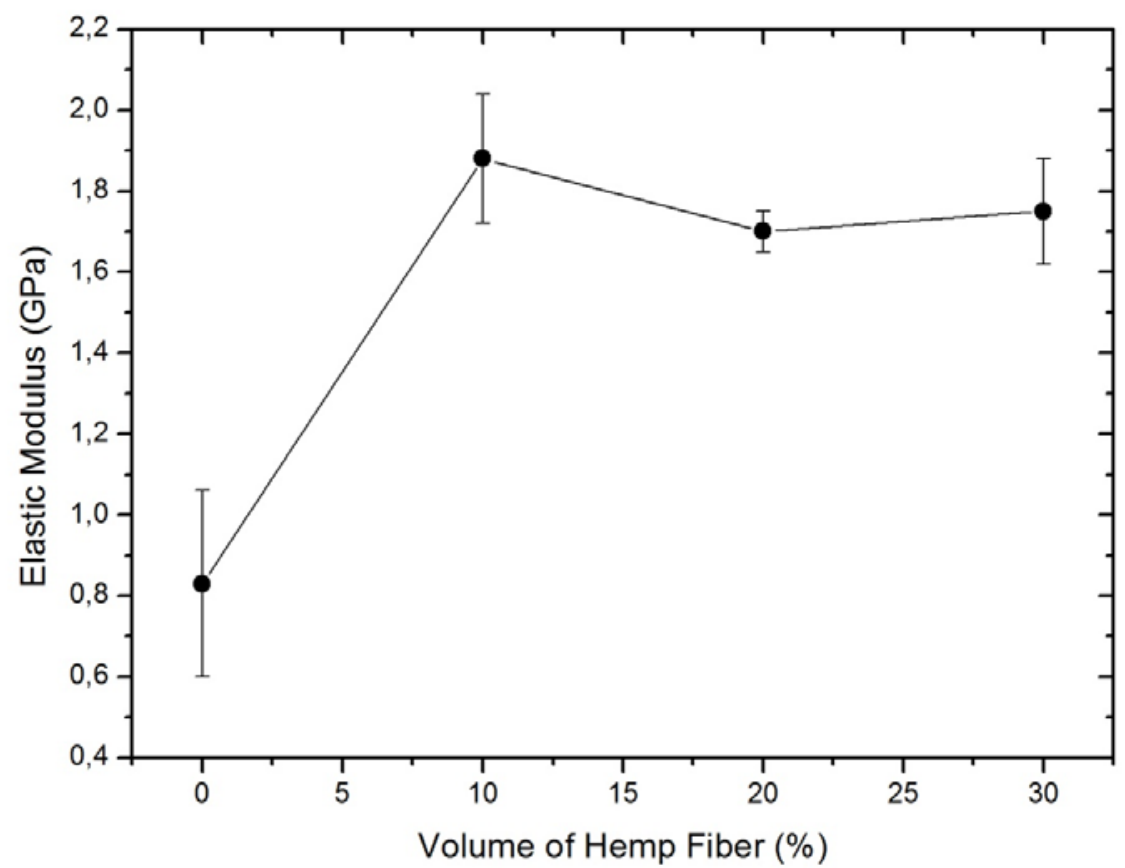

Figure 4. Variation of the elastic modulus with the volume fraction of eucalyptus fiber reinforcing polyester composites. 
The incorporation of continuous and aligned eucalyptus fibers significantly increases the tensile strength and stiffness of polyester matrix composites.

An apparent linear increase occurs up to a volume fraction of eucalyptus fiber of $30 \%$. This corresponds to a better performance than similar composite that were flexural tested.

Macroscopic evidences indicate that the strong eucalyptus fiber acts as effective barrier for rupture propagation throughout the brittle polyester matrix, in spite of the weak fiber matrix interface.

\section{CONCLUSION}

The incorporation of continuous and aligned eucalyptus fibers significantly increases the tensile strength and stiffness of polyester matrix composites.

An apparent linear increase occurs up to a volume fraction of eucalyptus fiber of $30 \%$. This corresponds to a better performance than similar composite that were flexural tested.

Macroscopic evidences indicate that the strong eucalyptus fiber acts as effective barrier for rupture propagation throughout the brittle polyester matrix, in spite of the weak fiber matrix interface.

\section{REFERÊNCIAS}

1 S. Hill, "Cars that grow on trees". New Scientists, 153(2067) (1997) 36-39.

2 G. Marsh, "Next step for automotive materials". Mater. Today, 6(4) (2003) 36-43

3 R. Zah, R. Hischier, A.L. Leão, I. Brown, "Curaua fibers in automobile industry - A sustainability assessment". J. Cleaner Production, 15, (2007) 1032-1040.

4 G. Marsh, "Next step for automotive materials". Mater. Today, 6(4) (2003) 36-43.

5 S. Hill, "Cars that grow on trees". New Scientists, 153(2067) (1997) 36-39.

6 R. Zah, R. Hischier, A.L. Leão and I. Brown, "Sisal fibers in automobile industry - A sustainability assessment". J. Cleaner Production, 15, (2007) 1032-1040.

7 R. Zah, R. Hischier, A.L. Leão and I. Brown, "Sisal fibers in automobile industry - A sustainability assessment". J. Cleaner Production, 15, (2007) 1032-1040

8 J.R.M. d'Almeida, R.C.M.P. Aquino and S. N. Monteiro, "Tensile Mechanical Properties, Morphological Aspects and Chemical Characterization of Piassava (Attalea funifera) Fibers". Composites. Part A, 37 (2006), 1473-1479.

9 C. Z. Paiva Jr., L.H. Carvalho, V.M. Fonseca, S.N. Monteiro, J.R.M. d'Almeida, "Analysis of the tensile strength of polyester/hybrid ramie-cotton fabric composites", Polymer Testing, 23(2) (2004) 131-135.

10 S.N. Monteiro, R.C.M.P. Aquino, F.P.D. Lopes, E.A. Carvalho and J.R.M. d'Almeida, "Mechanical Behavior and Structural Characteristics of Polymeric Composites Reinforced with Continuous and Aligned Curaua Fibers" (in Portuguese), Rev. Mater., 11(3) (2006) 197-203.

11 R.S. Santos, E.L.C. Silveira and C.M.L. Souza, "Study of the mechanical properties of thermoset polymeric matrix composites reinforced wit buriti fibers" (in Portuguese), Proceedings of the 30th Annual Meeting of the Brazilian Chemistry Society, (Aguas de Lindoia, Brazil, 2007) 1.

12 S.N. Monteiro, J.F. de Deus and J.R.M. d'Almeida, "Interfacial Strength of Sisal Fiber Reinforced Polyester Composites", Proceedings of SAM-CONAMET (Mar del Plata, Argentina, 2005) 1-6.

13 S.N. Monteiro, R.C.M.P. Aquino, F.P.D. Lopes, E.A. Carvalho and J.R.M. d'Almeida, "Mechanical behavior and structural characteristics of polymeric composites reinforced with continuous and aligned curaua fibers". Rev. Mater, 11(3) (2006) 197-203. 
14 S.N. Monteiro, J.F. de Deus and J.R.M. d'Almeida, "Mechanical and structural characterization of curaua fibers", Proceedings of Characterization of Minerals, Metals \& Materials - TMS Conference, (San Antonio, USA, March, 2006) 1-8.

15 K.G. Satyanarayana, J.L. Guimarães, F. Wypych, "Studies on lignocellulosic fibers of Brazil. Part I: Source, production, morphology, properties and applications". Composites: Part A, 38, (2007) 1694-1709.

16 S.N. Monteiro, R.C.M.P. Aquino, and F.P.D. Lopes, "Performance of sisal fibers in pullout tests". J. Mater. Sci. 43 (2008) 489-493.

17 S.N. Monteiro, A.S. Ferreira and F.P.D. Lopes, "Rupture mechanisms in composites reinforced with sisal fibers", Proceedings of Characterization of Minerals, Metals \& Materials - TMS Conference, (New Orleans, USA, March, 2008) 1-8.

18 R.V. Silva, E.M.F. Aquino, L.P.S. Rodrigues and A.R.F. Barros, "Curaua/Glass Hybrid Composite: The Effect of Water Aging on the Mechanical Properties", J. Reinforced Plast. \& Comp., 28 (2009) 1857-1868.

19 S.N. Monteiro, A.S. Ferreira and F.P.D. Lopes, "A comparative study of sisal fiber reinforced epoxy matrix composites as building materials", Proceedings of the Global Symposium on Recycling, Waste Treatment and Clean Technology - REWAS2008, (Cancun, Mexico, October 2008) 1653-1658.

20 R.V. Silva and E.M.F. Aquino,"Curaua fiber: A new alternative to polymeric composites", J. Reinforced Plast. \& Comp., 27(1) (2008) 103-112.

21 S.N. Monteiro, A.S. Ferreira and F.P.D. Lopes, "Pullout tests of curaua fibers in epoxy matrix for evaluation of interfacial strength", Proceedings of Characterization of Minerals, Metals \& Materials - TMS Conference, (San Francisco, USA, March, 2009) 1-7.

22 S.N. Monteiro, A.S. Ferreira and F.P.D. Lopes, "Izod impact energy of polyester matrix composites reinforced with aligned curaua fibers", Proceedings of Characterization of Minerals, Metals \& Materials - TMS Conference, (San Francisco, USA, March, 2009)1-8. 